\title{
Preliminary Column Study and Biosorption Kinetic Profile of Cadmium (II) by Epichlorohydrin-Crosslinked Lumbang (Aleurites molucanna) Chitosan Composite
}

\author{
NELSON R. VILLARANTE ${ }^{1}$, JERIEL JON D. TUMPALAN ${ }^{1}$ and DERICK ERL P. SUMALAPAO ${ }^{2,3 *}$ \\ 'Department of Physical Sciences and Mathematics, College of Arts and Sciences, \\ University of the Philippines Manila, Manila, Philippines. \\ ${ }^{2}$ Department of Medical Microbiology, College of Public Health, University of the Philippines Manila, \\ Manila, Philippines. \\ ${ }^{3}$ Biology Department, College of Science, De La Salle University, Manila, Philippines. \\ ${ }^{*}$ Corresponding author E-mail: dpsumalapao1@up.edu.ph
}

http://dx.doi.org/10.13005/ojc/350124

(Received: December 04, 2018; Accepted: January 13, 2019)

\begin{abstract}
In this study, the biosorption potential of lumbang (Aleurites molucanna)-derived activated carbon towards $\mathrm{Cd}$ (II) in aqueous solution was investigated by coating and crosslinking the adsorbent with chitosan and epichlorohydrin, respectively. Batch adsorption studies were performed and the effects of various parameters were evaluated. Results have shown that the optimum biosorption potential occurs at $\mathrm{pH}: 6.0$, contact time: $45 \mathrm{~min}$, temperature: $40^{\circ} \mathrm{C}$, adsorbent dosage: $12 \mathrm{~g} / \mathrm{L}$, and initial $\mathrm{Cd}(\mathrm{II})$ concentration: $5 \mathrm{ppm}$. The biosorption kinetic profile obeyed the pseudo second-order kinetic model $\left(R^{2}=96.87 \%, p<0.001\right)$. Preliminary column study and waste water analysis revealed significant removal of $\mathrm{Cd}(\mathrm{II})$, with $89.59 \%$ and $49.08 \%$ of $\mathrm{Cd}(\mathrm{II})$ adsorbed and desorbed, respectively. There were significant reductions in the biochemical and chemical oxygen demand values of the waste water before and after passing through the column.
\end{abstract}

Keywords: Aleurites molucanna, Batch adsorption study, Kinetic profile, Carbon-chitosan composite, Epichlorohydrin crosslinking, Column study

\section{INTRODUCTION}

The continuous quality deterioration of bodies of water has become an increasing environmental concern in cities undergoing economic growth ${ }^{1}$. One of the major causes of water pollution is the increasing discharge of various heavy metals into urban and rural waterways. These heavy metals, aside from being generally non-biodegradable, are also linked to several physiological disorders. In the Philippines, for example, a previous study had detected relatively higher concentrations of heavy metals such as $\mathrm{Cd}(\mathrm{II})$ in both riverine and marine sources compared to other locations ${ }^{2}$. Cadmium (II) is a highly toxic heavy metal which causes significant adverse physiological effects on both plants ${ }^{3}$ and humans ${ }^{4}$.

This is an Open Access article licensed under a Creative Commons license: Attribution 4.0 International (CC- BY). Published by Oriental Scientific Publishing Company @ 2018 
Within the past three decades, several methods have been developed overtime to facilitate the removal of heavy metals from water systems. Some of the earlier developed removal processes include membrane filtration, chemical precipitation, and ion exchange chromatography ${ }^{5}$. One of the most effective, economical, and environment-friendly methods is adsorption. Over time, researches have focused on the adsorption capabilities of different materials: biological materials, oxides, activated carbons, and polymer resins ${ }^{6}$. Among these, the use of activated carbon (AC) has become increasingly popular $7,8,9,10,11,12,13$, and it is highly favored due to its relative ease of regeneration, favorable adsorption kinetics, high adsorption capacity, and significant resistance to abrasion. There is a reliable number of sources for the production of activated carbon from agricultural wastes, such as coconut shells ${ }^{12}$ and calamansi peels ${ }^{14}$, as alternative to coal and lignocellulosic materials ${ }^{15}$. However, commerciallyproduced AC still remains relatively expensive, which is why the demands for alternative sources are on the rise. Researchers have now greatly shifted interest on the utility of agricultural wastes in developing countries as possible sources of activated carbon.

Another ideal method of increasing adsorption capacity of activated carbon is through coating it with chitosan. Chitosan, a linear polysaccharide derived from chitin deacetylation through treatment with an alkaline substance such as sodium hydroxide is known to have good complexing and chelating abilities due to its $-\mathrm{NH}_{2}$ groups that are involved in specific interactions with metals, therefore it has been an ideal material used for complexation of heavy metals ${ }^{9}, 10,11,16$. Hence, this study assessed the biosorption potential of lumbang-derived activated carbon by coating with chitosan and crosslinking with epichlorohydrin towards $\mathrm{Cd}$ (II) from an aqueous solution. In particular, the study evaluated the adsorption capacity and biosorption kinetic profile of epichlorohydrin-crosslinked lumbang activated carbon-chitosan composite in the removal of Cd(II) using different kinetic models. The study focused on the efficient and low-cost preparation of activated carbon derived from Aleurites molucanna (lumbang) seeds, coated with chitosan to generate a composite, and finally crosslinked with epichlorohydrin (ECH). To further assess the efficiency of the adsorbent, batch and preliminary column studies were also performed. The preparation of $A C$ from the lumbang seeds was a relatively simple and economical method that can be easily replicated. This will be useful for the general remediation of bodies of water that have been severely polluted due to improper disposal of toxic waste products from industries and factories, and for the treatment of water samples in remote communities which do not have access to both water cleaning facilities and purification processes.

\section{MATERIALS AND METHODS}

\section{Materials and Reagents}

Seeds of lumbang (Aleurites molucanna) tree were obtained from the University of the Philippines (College of Forestry), Los Baños, Laguna, Philippines. The $75 \%$ deacetylated chitosan and commercial epichlorohydrin were purchased from Sigma-Aldrich. Cadmium nitrate tetrahydrate was purchased from Fluka. Other reagents were provided by the Chemistry Laboratory, University of the Philippines (Department of Physical Sciences \& Mathematics, College of Arts \& Sciences), Manila, Philippines.

\section{Preparation of Charcoal}

The meat from lumbang seeds was removed, and the shells were washed and sundried for a week. The lumbang shells were pyrolyzed following the method in previous studies ${ }^{9,10,11,13}$ with slight modifications. Approximately $3 \mathrm{~kg}$ of lumbang shells were placed in a burrow with a diameter of $2 \mathrm{ft}$ and a depth of $3 \mathrm{ft}$. The raw material was ignited; after 30 min of burning, the pit was immediately covered with a flat galvanized iron and sand to initiate pyrolytic condition. After $12 \mathrm{~h}$, the charcoal was removed, washed $(3 \mathrm{x})$ with DI water, and oven-dried at $150{ }^{\circ} \mathrm{C}$ for 4 hours. The charcoal was then ground, sieved to $40-60$ mesh $(250-420 \mu \mathrm{m})$, and dried at $100^{\circ} \mathrm{C}$ for 24 hours.

\section{Physical Activation of Lumbang Charcoal}

About $50 \mathrm{~g}$ of lumbang charcoal was added with $100 \mathrm{~mL}$ of DI water and heated in the oven to $150{ }^{\circ} \mathrm{C}$ for 24 hours. The procedure was repeated using another $50 \mathrm{~g}$ of lumbang charcoal but after heating in the oven for $12 \mathrm{~h}$ the sample was transferred to the furnace for further activation. The furnace was ramped at $25{ }^{\circ} \mathrm{C} / \mathrm{min}$ until the heating temperature reached $600{ }^{\circ} \mathrm{C}$, keeping the temperature constant for an hour. After cooling, the 
activated carbon was washed $(5 \mathrm{x})$ with DI water and oven-dried at $110^{\circ} \mathrm{C}$ for 24 hours. The dried sample was sieved using 40-60 mesh (250-420 $\mu \mathrm{m})$.

\section{Chemical Activation of Lumbang Charcoal}

For the oven activation, solid activating agent $\mathrm{KOH}$ was mixed separately with inactivated charcoal in 2:1 ratio. The mixture was prepared by dissolving $20 \mathrm{~g}$ of the activating agent in $50 \mathrm{~mL}$ DI water and then amended with $10 \mathrm{~g}$ biocharcoal. The mixture was stirred for $2 \mathrm{~h}$ at $100^{\circ} \mathrm{C}$, subsequently transferred to the oven and heated further to $150{ }^{\circ} \mathrm{C}$ for 24 hours. The activated carbon was washed with DI water until neutral $\mathrm{pH}$ and dried at $110^{\circ} \mathrm{C}$ for 24 hours.

For the furnace activation, a similar procedure was employed as above except that the activation in the oven lasted only for $12 \mathrm{~h}$ prior to transfer to the furnace to complete the $24 \mathrm{~h}$ activation process. The activation of carbon using $\mathrm{KOH}$ was done in two ratios (2:1 and 1:2, $\mathrm{KOH}$ :carbon).

All activated samples were cooled, washed with $\mathrm{DI}$ water to neutral $\mathrm{pH}$, and oven-dried at $110^{\circ} \mathrm{C}$ for 24 hours. The dried sample was sieved using 40-60 mesh $(250-420 \mu \mathrm{m})$.

\section{Preparation of Lumbang Activated Carbon-} Chitosan (LAC-CHI) Composite

Chitosan $(2.5 \mathrm{~g})$ was introduced into a solution $(100 \mathrm{~mL})$ containing $10 \%$ oxalic acid ${ }^{9,10,11}$, stirred (550 rpm) and heated to $50{ }^{\circ} \mathrm{C}$ for 1 hour. Calcium chloride-activated carbon (CaLAC, $25 \mathrm{~g}$ ) was gradually added to the mixture and stirred (550 rpm) at $50^{\circ} \mathrm{C}$ for 24 hours. The solution was poured into a beaker containing $50 \mathrm{~mL}$ of $0.5 \%$ $\mathrm{NaOH}$ and stirred for $1 \mathrm{~h}$ before it was washed with $\mathrm{DI}$ water to neutral $\mathrm{pH}$ and dried at $100{ }^{\circ} \mathrm{C}$ for 24 hours. kalium hydroxide-activated carbon (KLAC) was prepared in a similar manner. The second coating with chitosan for the two activated carbons was done by repeating the above procedure using the same amount of chitosan $(2.5 \mathrm{~g})$.

Optimization of Potassium Hydroxide-Lumbang Activated Carbon-Chitosan Composite crosslinked with Epichlorohydrin (KLAC-CHI-ECH)

Potassium hydroxide-lumbang activated carbon-chitosan (coated twice) composite (KLAC) was crosslinked with $0.3125 \mathrm{M}$ epichlorohydrin in three different ratios: 1:2; $1: 1$, and 2:1 (mmol epichlorohydrin: $\mathrm{g}$ carbon). The resulting solution was stirred (350 rpm) to $50^{\circ} \mathrm{C}$ for 6 hours. The solution was then filtered, washed until neutral $\mathrm{pH}$, and dried at $110^{\circ} \mathrm{C}$ for 24 hours. The dried sample was sieved using 40-60 mesh $(250-420 \mu \mathrm{m})$.

\section{Preparation of $\mathrm{Cd}$ (II) Stock Solution}

A 1000 ppm Cd(II) stock solution was prepared by dissolving $0.6860 \mathrm{~g}$ of cadmium nitrate tetrahydrate, $\left.\mathrm{Cd}\left(\mathrm{NO}_{3}\right)_{2}\right)_{2} 4 \mathrm{H}_{2} \mathrm{O}$, with DI water in a $250 \mathrm{~mL}$ volumetric flask, and subsequently diluted to obtain the desired concentrations.

\section{Adsorption Parameters}

Various parameters contributing to the overall adsorption efficiency and capacity of the LAC-CHI-ECH composites were elucidated in this study. All experiment setups were carried out in triplicate. Batch adsorption study was performed using $15-\mathrm{mL}$ falcon tubes by soaking the prepared adsorbent in $10 \mathrm{~mL} \mathrm{Cd}$ (II) solutions. It was then agitated (155 rpm)using a Haier SHZ-82A constant temperature water bath shaker. Sample analysis was performed using atomic absorption spectrophotometer (Shimadzu AA-6300) by considering the following parameters.

\section{$\mathrm{pH}$}

This parameter was investigated over $\mathrm{pH}$ values $4-9$. Batch studies were performed in $15-\mathrm{mL}$ falcon tubes with desired concentrations of adsorbent $(0.09 \mathrm{~g})$ and $\mathrm{Cd}(\mathrm{II})$ solution (10 ppm). The tubes were agitated at $155 \mathrm{rpm}$ for $3 \mathrm{~h}$ at $30^{\circ} \mathrm{C}$.

\section{Contact time}

This parameter was investigated $15-180$ min interval, with the rate of adsorption measured every 15 minutes. The samples were prepared by soaking $0.09 \mathrm{~g}$ adsorbent in a $\mathrm{pH} 6$ solution of 10 ppm Cd(II).

\section{Temperature}

This parameter was investigated over working temperatures ranging from $20-90^{\circ} \mathrm{C}$. The same setup 
for the previous parameter was followed. The samples, maintained at $\mathrm{pH} 6$, were incubated at different temperatures for 45 minutes.

\section{Adsorbent dosage}

This parameter was investigated by soaking varying amounts of $\mathrm{AC}$ (0.05-0.14 g/L). Adsorption rate was monitored using the optimized conditions from previous parameters: $\mathrm{pH} 6,45 \mathrm{~min}$, and $40^{\circ} \mathrm{C}$.

\section{Cd(II) concentration}

This parameter was investigated by soaking the composites in $\mathrm{Cd}(\mathrm{II})$ solutions ranging from 5-30 ppm. Adsorption rate was monitored using the optimized conditions from previous parameters.

At the end of each experiment prior to analysis, all samples were filtered and analyzed using AAS for $\mathrm{Cd}(\mathrm{II})$ concentrations. The $\mathrm{Cd}(\mathrm{II})$ removal percentage was determined using the following equation:

$\%$ removal $=\frac{[\mathrm{Cd}(\mathrm{II})]_{\text {initial }}-[\mathrm{Cd}(\mathrm{II})]_{\text {final }}}{[\mathrm{Cd}(\mathrm{II})]_{\text {initial }}} \times 100$ Adsorption Kinetics

Adsorption kinetic studies were conducted by placing $0.12 \mathrm{~g}$ of the LAC-CHI-ECH composite in falcon tubes containing a $5 \mathrm{ppm} \mathrm{Cd}(\mathrm{II})$ solutions adjusted to $\mathrm{pH}$ 6.0. The falcon tubes were then incubated for $180 \mathrm{~min}$ in a water bath with a constant temperature and stirring rate of $40{ }^{\circ} \mathrm{C}$ and $155 \mathrm{rpm}$, respectively. Adsorption rate was monitored by analyzing triplicate samples every 15 minutes. The amount of adsorbate adsorbed at equilibrium, denoted qe $(\mathrm{mg} / \mathrm{g})$, was evaluated using the following equation:

$\mathrm{q}_{\mathrm{e}}=\frac{\left(\mathrm{C}_{\mathrm{o}}-\mathrm{C}_{\mathrm{e}}\right) \times \mathrm{V}}{\mathrm{m}}$

Where Co (initial) and $\mathrm{Ce}$ (equilibrium) the $\mathrm{Cd}(\mathrm{II})$ concentrations $(\mathrm{mg} / \mathrm{L}) ; \mathrm{m}(\mathrm{g})$ the mass of adsorbent; and $\mathrm{V}(\mathrm{L})$ the volume of solution.

To evaluate the kinetic mechanism governing the adsorption process, different biosorption kinetic models ${ }^{9,14}$ (zero, $1^{\text {st }}, 2^{\text {nd }}$, pseudo $1^{\text {st }}$, pseudo $2^{\text {nd }}$-order, and intraparticle diffusion equations) were explored.

\section{Preliminary Column Study of Cd(II) in Waste Water}

The optimized LAC-CHI-ECH composite was tested on laboratory waste water obtained from the chemistry laboratories of University of the Philippines Manila, Philippines. Prior to analysis, the waste water was filtered and subjected to hot plate acid digestion by mixing 5-mL of aqua regia to $20 \mathrm{~mL}$ of the filtered sample, allowing the mixture to boil for $45 \mathrm{~min}$ to an hour. The remaining samples were diluted to mark with DI water in a $50-\mathrm{mL}$ volumetric flask, then analyzed for heavy metal content using the AAS.

The preliminary column study for $\mathrm{Cd}(\mathrm{II})$ in an aqueous solution was conducted following the method in previous studies ${ }^{17,18,19}$ with slight modifications. A glass column (ID: $2.5 \mathrm{~mm}$, length: 21 $\mathrm{cm}$, and reservoir: $100 \mathrm{~mL}$ ) was used. The adsorbent was packed between glass wool and quartz sand to prevent disruption. A known quantity of adsorbent (approximately $3.2 \mathrm{~g}$ ) was placed in the column to reach the desired bed height $(15.6 \mathrm{~cm})$. A known volume of $10 \mathrm{ppm} \mathrm{Cd(II)} \mathrm{solution} \mathrm{was} \mathrm{passed} \mathrm{through}$ the glass column connected to a peristaltic pump (flow rate: $25 \mathrm{~mL} / \mathrm{min}$ ). Two $50-\mathrm{mL}$ aliquots were collected then analyzed using the AAS to determine $\mathrm{Cd}(\mathrm{II})$ concentrations. For the desorption analysis, $2 \mathrm{M} \mathrm{HNO}_{3}(100 \mathrm{~mL})$ was passed through the same column. Two 50-mL aliquots were collected and analyzed via AAS.

Determination of the total biological and chemical oxygen demand (BOD and COD) before and after adsorption was also performed on waste water. Approximately $250 \mathrm{~mL}$ of the filtered (undigested) waste water was allowed to pass through the column, following the same procedure described above. The resulting samples were then sent to Cleoras Corp. for BOD and COD analysis.

\section{RESULTS AND DISCUSSION}

\section{Optimization of $\mathrm{KOH}-\mathrm{AC}$ ratio}

The $\mathrm{KOH}$-activated and furnace-dried carbon resulted in $94.42 \%$ removal of $\mathrm{Cd}$ (II) in an aqueous solution. The present study demonstrated the favorable effects of $\mathrm{KOH}$ as an activating agent. The adsorption capacity of the $1: 2 \mathrm{KOH}-\mathrm{AC}$ ratio was $98.89 \%$, while the $2: 1 \mathrm{KOH}-\mathrm{AC}$ ratio was 98.64\%. However, there is no significant difference between the two ratios ( $p>0.05)$. In the succeeding experiment, the 1:2 $\mathrm{KOH}-\mathrm{AC}$ ratio was chosen for further optimization to limit the use of $\mathrm{KOH}$ as an activating agent.

\section{Optimization of LAC-CHI Composite crosslinked with Epichlorohydrin}

In this study, crosslinking the LAC-CHI composite with epichlorohydrin $(\mathrm{AC}: \mathrm{ECH})$ in three ratios (1:1, 1:2, and 2:1) showed significant difference in $\mathrm{Cd}(\mathrm{II})$ percent removal $(p=0.0198)$. However, the 
1:2 AC-ECH ratio had the highest percentage removal among the different samples tested
(Table 1), although the 1:1 ratio did not significantly differ with the 1:2 ratio $(p>0.05)$.

Table 1: Removal efficiency of lumbang activated carbon-chitosan composite crosslinked with epichlorohydrin at different crosslinker-carbon adsorbent ratios

\begin{tabular}{lccc}
\hline AC-ECH Ratio & $1: 1$ & $1: 2$ & $2: 1$ \\
Mean \pm standard deviation (\%) & $79.76 \pm 3.13^{\mathrm{a}, \mathrm{b}}$ & $83.37 \pm 4.10^{\mathrm{a}}$ & $69.00 \pm 5.96^{\mathrm{b}, \mathrm{c}}$ \\
\hline
\end{tabular}

AC-ECH: activated carbon crosslinked with epichlorohydrin

Identical superscript letters suggest that the means do not differ using Bonferroni test at $5 \%$.

\section{Batch Adsorption Studies of LAC-KOH-CHI(x2)- ECH Composite Effect of $\mathrm{pH}$}

In the present study, the maximum adsorption of $\mathrm{Cd}(\mathrm{II})$ was observed at $\mathrm{pH} 6.0$ (Fig. 1). Previous study ${ }^{6}$ had shown that the adsorption of $\mathrm{Cd}(\mathrm{II})$ is very low at $\mathrm{pH}<4.0$; however, it increases approximately 8 -fold within $\mathrm{pH} 4.0$ to 6.0 . The low adsorption capacity for $\mathrm{Cd}(\mathrm{II})$ can be attributed to the acidic condition of the solution. Moreover, depending on the $\mathrm{pH}$ of the solution, cadmium can exist in varying species and/or hydro-complexes ${ }^{20}$. Cadmium(II) in an aqueous solution predominates at $\mathrm{pH}<7.0$, although beginning at $\mathrm{pH} 8$, some of the $\mathrm{Cd}^{2+}$ ions in the solution is already present as $\mathrm{Cd}(\mathrm{OH})^{+}$, indicating that cadmium species other than $\mathrm{Cd}$ (II) have already formed ${ }^{20}$. This may explain why the percent removal begins to decrease as the $\mathrm{pH}$ exceeds 8.0. It has also been recorded that at $\mathrm{pH}>8.0, \mathrm{OH}^{-}$ions in solution begin to form complexes with cadmium, causing the decrease in percent removal.

\section{Effect of Contact Time}

The optimum contact time was observed at $45 \mathrm{~min}$ (Fig. 2). There was a rapid increase in percent removal within the first $15 \mathrm{~min}$, a slower increase was observed as time progressed, reaching its maximum percent removal at the 45 min-mark, before attaining equilibrium. This may be explained by the eventual saturation of the carbon surface with the metal ions.

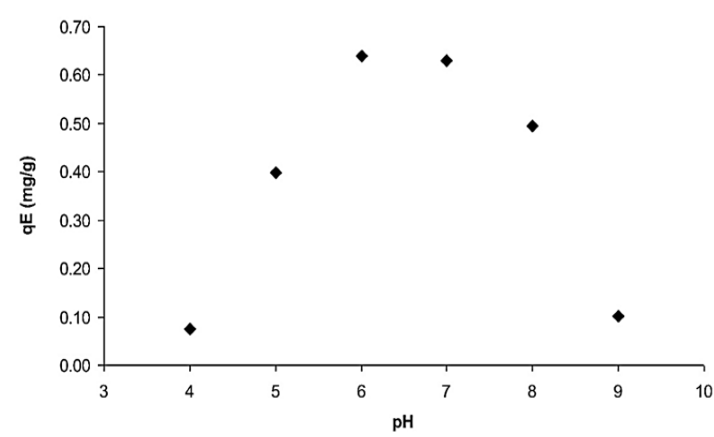

Fig. 1. Adsorption capacity at varying $\mathrm{pH}$ levels (contact time: $180 \mathrm{~min}$, temperature: $30^{\circ} \mathrm{C}$, solution volume: $10 \mathrm{~mL}$, heavy metal concentration: $10 \mathrm{ppm}$, adsorbent dosage: $9 \mathrm{~g} / \mathrm{L}$, agitation rate: $155 \mathrm{rpm}$ )

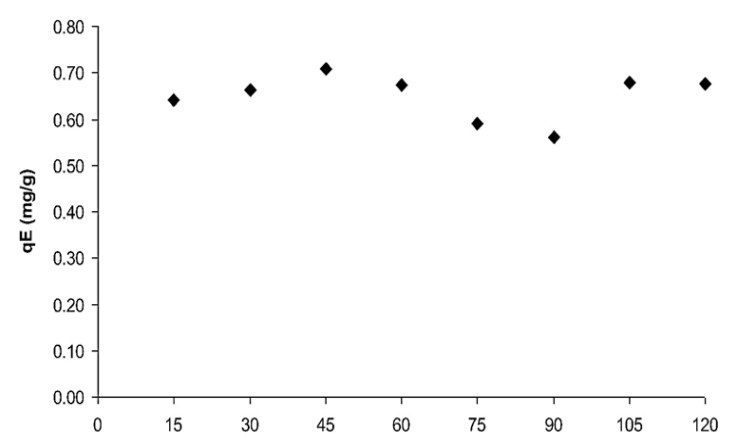

Fig. 2. Adsorption capacity at different contact times (pH: 6.0 , temperature: $30^{\circ} \mathrm{C}$, solution volume: $10 \mathrm{~mL}$, heavy metal concentration: $10 \mathrm{ppm}$, adsorbent dosage: $9 \mathrm{~g} / \mathrm{L}$, agitation rate: $155 \mathrm{rpm}$ )

\section{Effect of Temperature}

The highest $\mathrm{Cd}(\mathrm{II})$ percentage removal was observed at $40^{\circ} \mathrm{C}$ (Fig. 3). It can also be seen that even at higher temperatures, there was no observed significant change in the adsorption process.

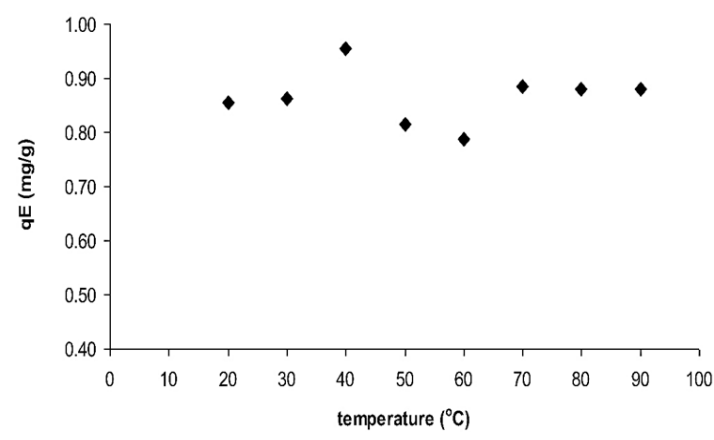

Fig. 3. Adsorption capacity at different temperature levels (pH: 6.0, contact time: $45 \mathrm{~min}$, solution volume: $10 \mathrm{~mL}$, heavy metal concentration: $10 \mathrm{ppm}$, adsorbent dosage: 9 $\mathrm{g} / \mathrm{L}$, agitation rate: $155 \mathrm{rpm}$ )

Effect of Adsorbent Dosage

The optimum adsorbent dose was observed at $12 \mathrm{~g} / \mathrm{L}$ (Fig. 4). At lower doses of the adsorbent, there were fewer adsorption sites present, thus the removal of the heavy metal is only to a certain extent. However, once the adsorbent dosage exceeds $12 \mathrm{~g} / \mathrm{L}$, there was already a visible decrease in 
Cd(II) percent removal. This may be attributed with the overcrowding of the adsorbent which may have caused the overlapping or blocking of some adsorption sites on the carbon surface.

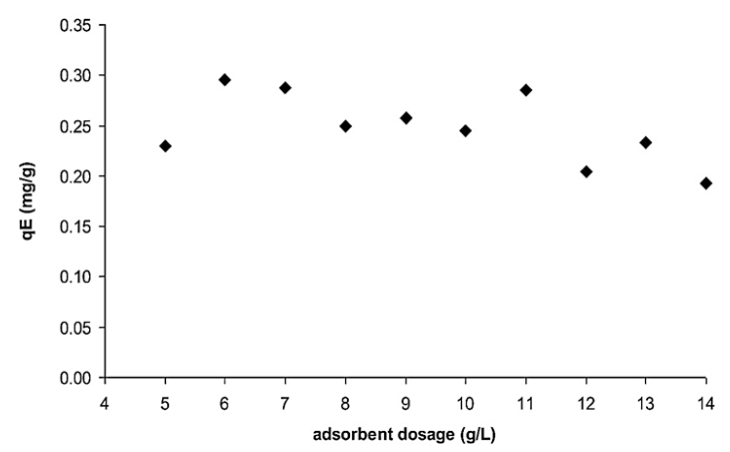

Fig. 4. Adsorption capacity at different adsorbent dosage values ( $\mathrm{pH}: 6.0$, contact time: $45 \mathrm{~min}$, temperature: $40^{\circ} \mathrm{C}$, solution volume: $10 \mathrm{~mL}$, heavy metal concentration: $10 \mathrm{ppm}$, agitation rate: $155 \mathrm{rpm}$ )

\section{Effect of Cd(II) initial concentration}

As shown in Fig. 5, the adsorbent exhibited its highest percent removal at 5 ppm initial concentration of $\mathrm{Cd}(\mathrm{II})$. Although there was an increase in $\mathrm{Cd}(\mathrm{II})$ initial concentration, a decrease in the percent removal of the metal was observed. This decline in the adsorption of $\mathrm{Cd}(\mathrm{II})$ is due to the limited number of adsorption sites and eventual saturation within the carbon surface.

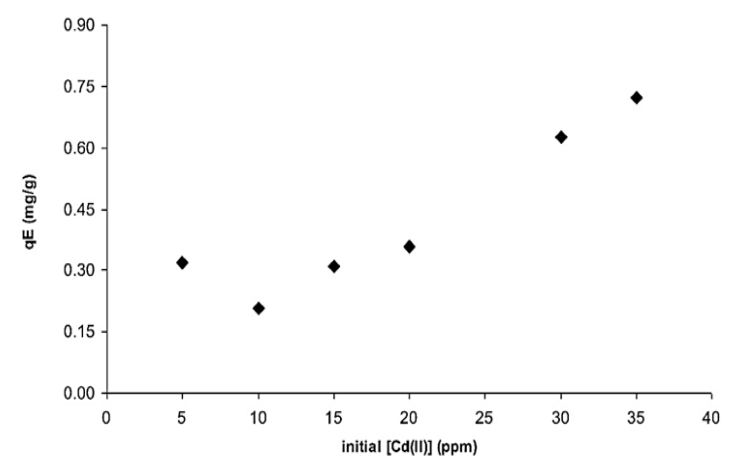

Fig. 5. Adsorption capacity at different $\mathrm{Cd}(\mathrm{II})$ initial concentrations ( $\mathrm{pH}: \mathbf{6 . 0}$, contact time: $45 \mathrm{~min}$, temperature: $40{ }^{\circ} \mathrm{C}$, solution volume: $10 \mathrm{~mL}$, adsorbent dosage: $12 \mathrm{~g} / \mathrm{L}$, agitation rate: $155 \mathrm{rpm}$ )

\section{Biosorption Kinetic Studies}

Kinetic studies are critical factors in studying adsorption mechanisms because it can help identify the mechanism that affects the adsorption properties of activated carbon. It has been observed that there is a great increase in the uptake of $\mathrm{Cd}(\mathrm{II})$ within the first 15 min then gradually slowing down until it reached equilibrium at the 45 min-mark (Fig. 6). This may already signal that the pores on the carbon surface are already filled with the heavy metal. When the different kinetic models (zero, $1^{\text {st }}, 2^{\text {nd }}$, and pseudo $1^{\text {st }}$-order) were investigated to study the adsorption kinetics of Cd(II) (Fig. 6-9), none of these models were adequate in describing its biosorption kinetic profile as justified by the low coefficient of determination $\left(R^{2}\right)$ and $p$-values exceeding the $5 \%$ level of statistical significance.

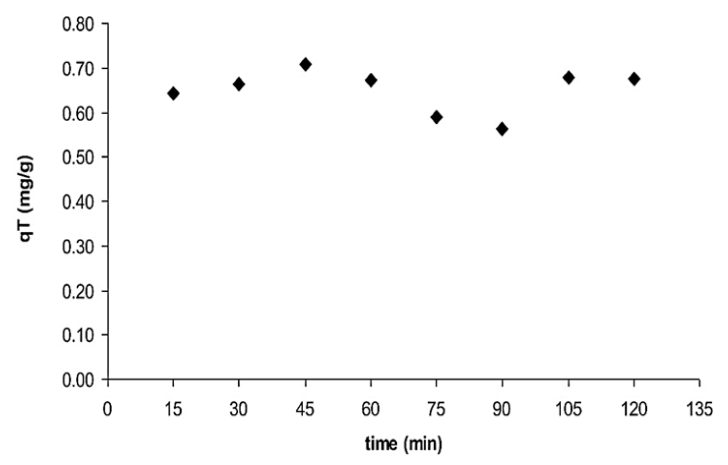

Fig. 6. $\mathrm{Cd}$ (II) adsorption described by the zero-order kinetic model $\left(R^{2}=1.56 \%, p>0.05\right)$

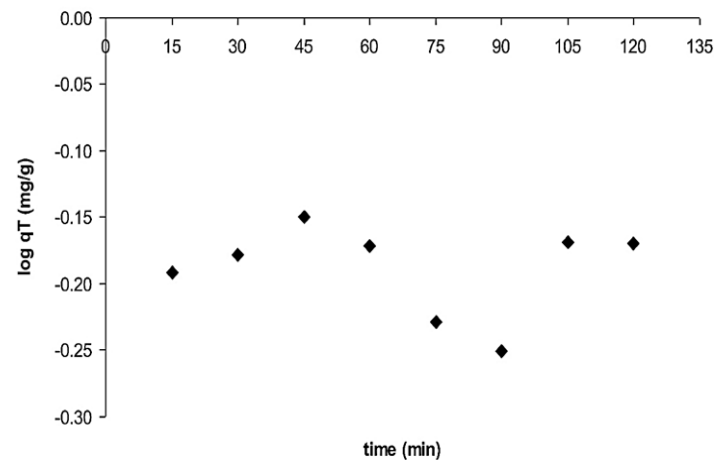

Fig. 7. Cd(II) adsorption described by the first-order kinetic model $\left(R^{2}=1.76 \%, p>0.05\right)$

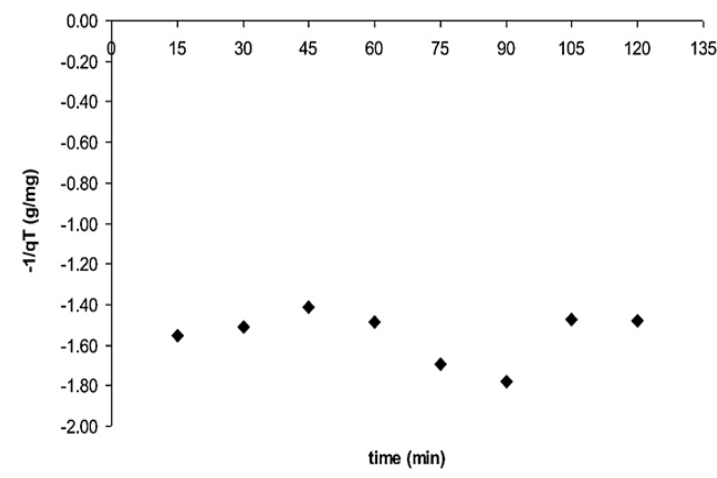

Fig. 8. Cd(II) adsorption described by the second order kinetic model $\left(R^{2}=1.97 \%, p>0.05\right)$ 


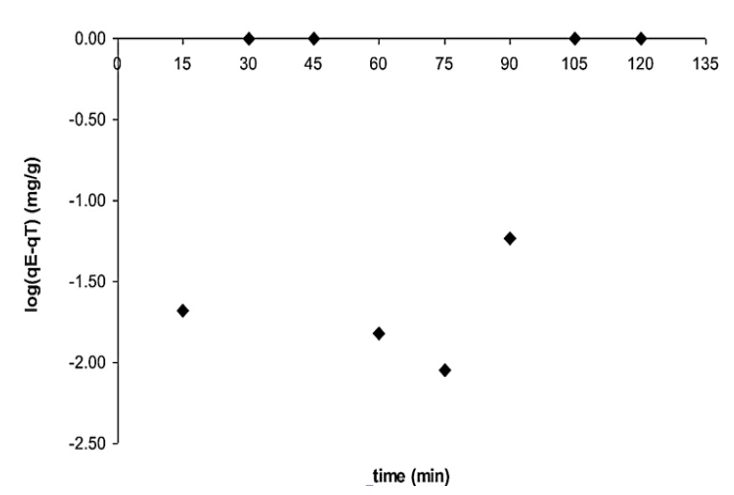

Fig. 9. Cd(II) adsorption described by the pseudo first-order kinetic model ( $q E$ calculated $=0.10, q E$ experimental $=6.90$, $R^{2}=0.23 \%, p>0.05$ )

However, the biosorption of $\mathrm{Cd}(\mathrm{II})$ can be best described by the pseudo $2^{\text {nd }}$-order kinetic equation (Fig. 10). The parameter estimates of this kinetic equation can be obtained, along with qe, from the slope and intercept of $t$ qt vs. t plots. This model suggests that the rate of adsorption is independent of the concentration of the adsorbate but depends on the available

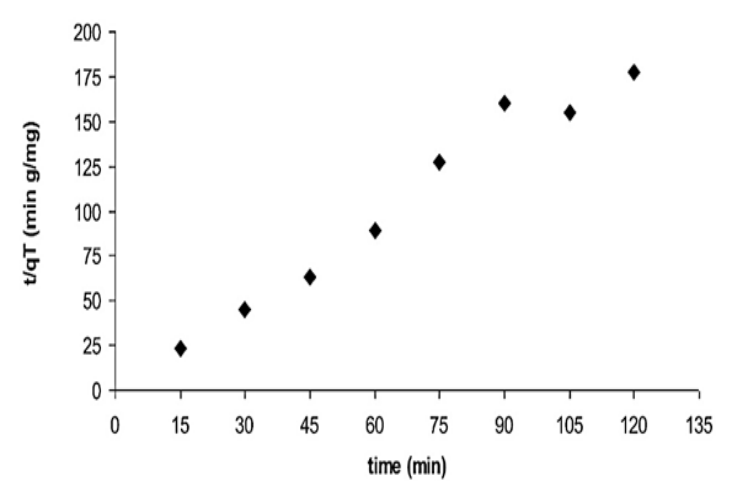

Fig. 10. Cd(II) adsorption described by the pseudo second-order kinetic model ( $q E$ calculated $=6.91, q E$ experimental $=6.90, \mathrm{R}^{2}=96.87 \%, \mathrm{p}<0.001$ )

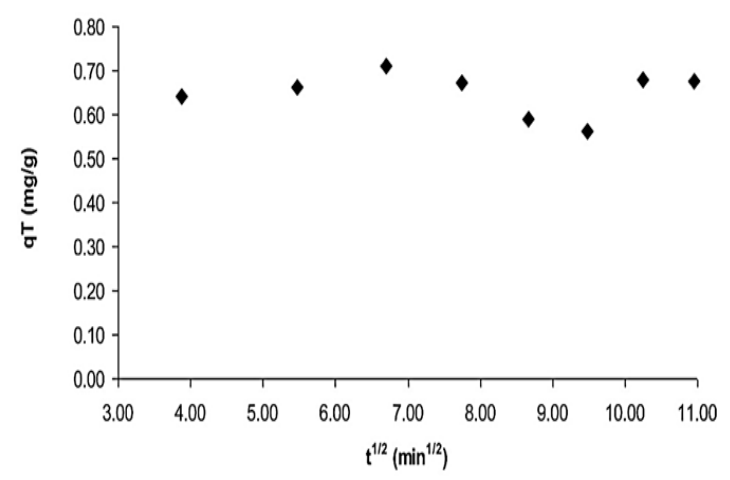

Fig. 11. The intraparticle diffusion kinetic model of $\mathrm{Cd}(\mathrm{II})$ adsorption $\left(R^{2}=1.85 \%, p>0.0 .5\right)$ adsorption sites in the solid phase ${ }^{21}$. Further, this model states that while physisorption is the main mechanism governing the adsorption process in a certain system, it is also to an extent affected by intraparticle diffusion and chemisorption. In the intraparticle diffusion model (Fig. 11), the intercept, $\mathrm{C}=0.6713$, describes the boundary layer thickness ${ }^{22}$.

\section{Preliminary Column Study}

Following adsorption-desorption analysis of a one-shot column run, relative percent adsorbed and percent desorbed of $\mathrm{Cd}$ (II) were $89.59 \%$ and $49.08 \%$, respectively. This finding suggests that the adsorbent has a relatively favorable adsorption and desorption capabilities, allowing for the quick retrieval of $\mathrm{Cd}(\mathrm{II})$ from the carbon surface. In the preliminary column study, the breakthrough point is reached when the concentration of the effluent has already reached at least $5 \%$ of its influent concentration. For the waste water analysis, it provides information regarding waste water loading. Reaching the breakthrough point suggests that the column is about to be fully saturated by the waste water contaminant. A greater breakthrough number then indicated higher column efficiency. On the other hand, the "point of column exhaustion" is where the effluent concentration has reached $95 \%$ of the initial concentration. In the present study, $\mathrm{Cd}(\mathrm{II})$ in a single-system solution reached its exhaustion after approximately $800 \mathrm{~mL}$ has passed through the column. The column already achieved its breakthrough point within the first $12 \mathrm{~mL}$ aliquot.

The optimized LAC-KOH-CHI(x2)-ECH adsorbent was applied to laboratory waste water contaminated with $\mathrm{Cd}(\mathrm{II})$. Acid digestion revealed that the original heavy metal concentration in the sample was less than $5 \mathrm{ppm}$. The waste water was therefore spiked with 100 ppm of the heavy metal solution and allowed to pass through the column. With an initial $\mathrm{Cd}$ (II) concentration of $100 \mathrm{ppm}$, a final reading of $27.1 \mathrm{ppm}$ was obtained after the column analysis suggesting a $72.9 \%$ removal. The favorable adsorption capacities of the LAC-KOH-CHI(x2)-ECH composite on waste water as expressed by the high percent removal of the heavy metal, extends the adsorbent's use not only to synthetic heavy metal solutions but also to the industrial waste as well.

In the present study, the biochemical oxygen demand (BOD) of the untreated waste water 
was determined to be $38.5 \mathrm{mg} / \mathrm{L}$, and when passed through a column, the BOD value dropped drastically to $4.2 \mathrm{mg} / \mathrm{L}$. On the other hand, the chemical oxygen demand (COD) of the untreated waste water was $74.0 \mathrm{mg} / \mathrm{L}$, while the column-treated waste water was $10.1 \mathrm{mg} / \mathrm{L}$. The superior adsorption capacity of the $\mathrm{LAC}-\mathrm{KOH}-\mathrm{CHI}(\mathrm{x} 2)-\mathrm{ECH}$ composite is reflected by the drastic decrease in both the BOD and COD values suggesting that the waste water has been efficiently cleaned after passing through the column.

\section{CONCLUSION}

A low-cost burrow method synthesis of activated carbon composite from the seeds of lumbang (Aleurites molucanna) tree, which was then double-coated with chitosan and cross-linked with epichlorohydrin as biosorbent for the removal of $\mathrm{Cd}(\mathrm{II})$ was investigated. The optimized parameters for adsorption were recorded at $\mathrm{pH} 6.0,45 \mathrm{~min}$ incubation time, $40{ }^{\circ} \mathrm{C}$ temperature, $5 \mathrm{ppm}$ initial $\mathrm{Cd}(\mathrm{II})$ concentration, and $12 \mathrm{~g} / \mathrm{L}$ adsorbent dosage.
The biosorption process behaved in accordance with the pseudo $2^{\text {nd }}$-order kinetic model. Preliminary column potential of the adsorbent using singlesystem had a breakthrough point at $800 \mathrm{~mL}$. Desorption tests showed that approximately $90 \%$ $\mathrm{Cd}(\mathrm{II})$ have already been desorbed within the first 50 $\mathrm{mL}$ of $2 \mathrm{M} \mathrm{HNO}_{3}$ suggesting a favorable desorption process. Adsorption studies on waste water of varying sources and chemical compositions and the effect of using different crosslinking agents or particle mesh sizes may be considered in future studies.

\section{ACKNOWLEDGMENT}

This work was supported by the National Institutes of Health, University of the Philippines Manila.

\section{CONFLICT OF INTEREST}

The authors declare that they do not have any disclosures.

\section{REFERENCES}

1. Hosono, T.; Siringan, F.; Yamanaka, T.; Umezawa, Y.; Onodera, S.; Nakano, T.; Taniguchi, M. Application of multi-isotope ratios to study the source and quality of urban groundwater in Metro Manila, Philippines. Applied Geochemistry., 2010, 25(6), 900-909.

2. Prudente, M.; Ichihashi, H.; Tatsukawa, R. Heavy metal concentrations in sediments from Manila Bay, Philippines and inflowing rivers. Environmental Pollution., 1994, 86(1), 83-88.

3. Das, P.; Samantaray, S.; Rout, G. Studies on cadmium toxicity in plants: a review. Environmental Pollution., 1997, 98(1), 29-36.

4. Järup, L.; Åkesson, A. Current status of cadmium as an environmental health problem. Toxicology and Applied Pharmacology., 2009, 238(3), 201-208.

5. Corapcioglu, M.; Huang, C. The adsorption of heavy metals onto hydrous activated carbon. Water Research., 1987, 21(9), 1031-1044.

6. Mohan, D.; Singh, K. Single- and multicomponent adsorption of cadmium and zinc using activated carbon derived from bagassean agricultural waste. Water Research. 2002, 36(9), 2304-2318.

7. Hu, Z.; Srinivasan, M.; Ni, Y. Preparation of mesoporous high-surface-area activated carbon. Advanced Materials., 2000, 12(1), 62-65.

8. Hydari, S.; Sharififard, H.; Nabavinia, M.; Parvizi, M. A comparative investigation on removal performances of commercial activated carbon, chitosan biosorbent and chitosan/activated carbon composite for cadmium. Chemical Engineering Journal., 2012, 193-194, 276-282.

9. Villarante, N.R.; Bautista, A.P.R.; Sumalapao, D.E.P. Batch adsorption study and kinetic profile of $\mathrm{Cr}(\mathrm{VI})$ using lumbang (Aleurites moluccana)-derived activated carbon-chitosan composite crosslinked with epichlorohydrin. Orient. J. Chem., 2017, 33(3), 1111-1119.

10. Bautista, A.P.R.; Sumalapao, D.E.P.; Villarante, N.R. Synthesis and characterization of epichlorohydrin crosslinked lumbang (Aleurites moluccana)-derived activated carbon chitosan composite as $\mathrm{Cr}(\mathrm{VI})$ bioadsorbent. Annual Research \& Review in Biology., 2017, 21(1), 1-7.

11. Villarante, N.R.; Bautista, A.P.R.; Sumalapao, D.E.P.Adsorption isotherm and thermodynamic profile of hexavalent chromium onto lumbang (Aleurites moluccana) activated carbon chitosan composite crosslinked with epichlorohydrin. Annual Research \& Review in Biology., 2018, 22(5), 1-9. 
12. Regunton, P.C.V.; Sumalapao, D.E.P.; Villarante, N.R.Biosorption of methylene blue from aqueous solution by coconut (Cocos nucifera) shellderived activated carbon-chitosan composite. Orient. J. Chem., 2018, 34(1), 115-124.

13. Villarante, N.R.; Davila, R.A.E.; Sumalapao, D.E.P.; Removal of lead (II) by lumbang, Aleurites moluccana activated carbon carboxymethylcellulose composite crosslinked with epichlorohydrin. Orient. J. Chem., 2018, 34(2), 693-703.

14. Sumalapao, D.E.P.; Distor, J.R.; Ditan, I.D.; Domingo, N.T.S.; Dy, L.F.; Villarante, N.R. Biosorption kinetic models on the removal of congo red onto unripe calamansi (Citrus microcarpa) peels. Orient. J. Chem., 2016, 32(6), 2889-2900.

15. Ahmadpour, A.;Do, D.The preparation of activated carbon from macadamia nutshell by chemical activation. Carbon., 1997, 35(12), 1723-1732.

16. Rinaudo, M. Chitin and chitosan: properties and applications. Progress in Polymer Science., 2006, 31(7), 603-632.

17. Borba, C.E.; Guirardello, R.; Silva, E.A.; Veit, M.T.; Tavares, C.R.G. Removal of nickel(II) ions from aqueous solution by biosorption in a fixed bed column: Experimental and theoretical breakthrough curves. Biochemical
Engineering Journal., 2006, 30, 184-191.

18. Sousa, F.W.; Oliveira, A.G.; Ribeiro, J.P.; Rosa, M.F.; Keukeleire, D.; Nascimento, R.F. Green coconut shells applied as adsorbent for removal of toxic metal ions using fixed-bed column technology. Journal of Environmental Management., 2010, 91, 1634-1640.

19. Futalan, C.M.; Kan, C.; Dalida, M.L.; Pascua, C.; Wan, M. Fixed-bed column studies on the removal of copper using chitosan immobilized on bentonite. Carbohydrate Polymers., 2011, 83, 697-704.

20. Reed, B.E.; Matsumoto, M.R. Modeling cadmium adsorption by activated carbon using the Langmuir and Freundlich isotherm expressions. Separation Science and Technology., 1993, 28(1-3), 2179-2195.

21. Azouaou, N.; Sadaoui, Z.; Djaafri, A.; Mokaddem, H. Adsorption of cadmium from aqueous solution onto untreated coffee grounds: equilibrium, kinetics, and thermodynamics. Journal of Hazardous Materials., 2010, 184, 126-134.

22. Kannan, N.; Sundaram, M.M. Kinetics and mechanisms of removal of methylene blue by adsorption in various carbons - a comparative study. Dyes and Pigments., 2001, 51(1), 25-40. 